DOI:

\title{
PERAN CENDAWAN ENDOFIT DAN PUPUK ANORGANIK DALAM MENINGKATKAN PRODUKSI DAN KETAHANAN PADI GOGO TERHADAP PENYAKIT BLAS (Pyricularia oryzae)
}

\section{THE ROLE OF ENDOPHYTIC FUNGI AND INORGANIC FERTILIZER TO INCREASE PRODUCTION AND RESISTANCE OF UPLAND RICE AGAINST BLAST DISEASE (Pyricularia oryzae)}

\author{
Ahmad Sainul $^{1}$, Muhammad Taufik ${ }^{2 *}$, Gusnawaty HS $^{2}$, Andi Khaeruni ${ }^{2}$, \\ Rachmawati Hasid $^{2}$, La Ode Santiaji Bande ${ }^{2}$ dan Muhammad Botek $^{3}$ \\ 1) Mahasiswa S2 Program Studi Agronomi Pascasarjana UHO \\ 2) Dosen Program Studi Agronomi ascasarjanas UHO \\ 3) Dosen Proteksi Tanaman Faperta UHO
}

Diterima: 29 Maret 2019/Disetujui: 20 Mei 2019

\begin{abstract}
This study aims to evaluated the effect of endophytic fungi and doses of inorganic fertilization to increasing the production and resistance of upland rice againts blast disease (Pirycularia oryzae). The research was conducted in Lamomea, Konda, South Konawe, Southeast Sulawesi, and Plant Protection Laboratory and Soil Science Laboratory, Faculty of Agriculture, Halu Oleo University, Kendari, in May 2018 until October 2018. This study used a Randomized Block Design (RBD) in factorial pattern with 2 factors, the first factor was fertilization consisting of: without inorganic fertilizer (PO), fertilizing with 25\% inorganic fertilizer from recommendation (P1), ), fertilizing with $50 \%$ inorganic fertilizer from recommendation (P2), fertilizing with 75\% inorganic fertilizer from recommendation (P3), fertilizing with $100 \%$ inorganic fertilizer from recommendation (P4), and the second factor used endophytic fungi consisting of: without application of endopytic fungi (CO), application of Trichoderma asperellium (C1) and application Paecilomyces sp. (C3). The data observation were analyzed using the variance method and continued with Duncan's Multiple Distance Test (UJBD). The result showed that there was interaction of fertilization inorganic and endophytic fungi on variable of plant height, numver of tillers, time appears panicles, weight of 1000 grains, dry grain yield and disease severity. The combination of $75 \%$ inorganic fertilizer treatment according to recommendations with endophytic fungi Trichoderma sp. (P3C1) and the treatment of 75\% inorganic fertilizer with Paecilomyces sp. (P3C2) give the best response in increasing the production and resistance of upland rice to blast disease.
\end{abstract}

Keywords: Upland rice, Endophytic fungi, inorganic fertilizer, Pyricularia oryzae, blast

\section{ABSTRAK}

Penelitian bertujuan mengevaluasi pengaruh cendawan endofit dan dosis pupuk anorganik dalam meningkatkan produksi dan ketahanan padi gogo terhadap penyakit blas ( $P$. oryzae). Penelitian ini menggunakan Rancangan Acak Kelompok (RAK) dalam pola faktorial dengan 2 faktor yaitu faktor pertama adalah pemupukan yang terdiri dari: tanpa pupuk anorganik (P0), pemupukan dengan pupuk anorganik 25\% dari rekomendasi (P1), pemupukan dengan pupuk anorganik 50\% dari rekomendasi (P2), pemupukan dengan pupuk anorganik $75 \%$ dari rekomendasi (P3), pemupukan dengan pupuk anorganik $100 \%$ sesuai rekomendasi (P4) dan faktor kedua adalah penggunaan cendawan endofit yang terdiri dari: tanpa aplikasi cendawan endofit (C0), aplikasi T. asperellium (C1) dan aplikasi Paecilomyces sp. (C2). Data hasil pengamatan dianalisis menggunakan metode sidik ragam dan dilanjutkan dengan Uji Jarak Berganda Duncan (UJBD). Hasil penelitian menunjukkan bahwa ada interaksi pemupukan dengan pupuk anorganik dan cendawan endofit pada variabel tinggi tanaman, jumlah anakan, waktu muncul malai, bobot 1000 bulir, hasil gabah kering dan keparahan penyakit. Kombinasi perlakuan pupuk anorganik 75\% sesuai rekomendasi dengan cendawan endofit Trichoderma sp. (P3C1) dan Perlakuan pupuk anorganik 75\% denganPaecilomyces sp. (P3C2) memberikan respon terbaik dalam meningkatkan produksi dan ketahanan padi gogo terhadap penyakit blas.

Kata kunci, padi gogo, cendawan endofit, pupuk organik, blas

\footnotetext{
${ }^{*}$ Penulis untuk korespondensi. Email : taufik24@yahoo.com
} 


\section{PENDAHULUAN}

Padi (Oryza sativa L.) merupakan komoditas tanaman pangan nasional yang sangat penting. Penduduk Indonesia menjadikan beras sebagai bahan makanan pokok, konsumsi beras di Indonesia sangat tinggi mencapai $95 \%$ dengan mencukupi $63 \%$ total kecukupan energi dan $37 \%$ protein. Kebutuhan beras akan terus meningkat dari tahun ke tahun dengan asumsi pertumbuhan penduduk $2 \%$ per tahun dan perubahan pola konsumsi penduduk dari non beras ke beras. Sebaliknya ancaman stabilitas produksi beras, karena perubahan status lahan sawah irigasi subur akibat konversi lahan untuk kepentingan non pertanian serta munculnya fenomena degradasi kesuburan menyebabkan produktivitas padi sawah irigasi menurun sehingga tidak mampu mengimbangi laju peningkatan penduduk (Sitohang, 2014).

Produktivitas padi gogo dipengaruhi oleh beberapa hal diantaranya kesuburan tanah yang rendah, tehnik budidaya tradisional yang diterapkan dan adanya gangguan patogen jamur $P$. oryzae. Pemanfaatan cendawan endofit dan teknik pemupukan dengan pupuk anorganik menjadi bagian penting dalam budidaya padi gogo. Hasfiah et al. (2012) melaporkan bahwa pengaturan dosis pemupukan seperti pupuk urea secara tepat dapat meningkatkan pertumbuhan padi gogo dan ketahanan terhadap penyakit.

Cendawan endofit salah satu mikroorganisme yang dianggap potensial dalam pembentukan tanaman padi yang resisten. Clay (1998) dalam Ariyanto (2013) menyebutkan bahwa cendawan endofit terdapat di dalam sistem jaringan tumbuhan, seperti daun, bunga, ranting ataupun akar tumbuhan. Interaksi antara cendawan endofit dan inang tanaman umumnya bersifat simbiosis mutualisme. Cendawan endofit dapat menginfeksi tumbuhan sehat pada jaringan tertentu dan mampu menghasilkan mikotoksin, enzim serta antibiotika. Asosiasi beberapa cendawan endofit dengan tumbuhan inangnya mampu melindungi beberapa tumbuhan inangnya dari beberapa patogen virulen, kondisi ekstrim maupun herbivora.

Damanik et al. (2013) melaporkan perlakuan Trichoderma sp. (cendawan endofit) atau Pseudomonas fluorescens menunjukkan adanya penurunan intensitas serangan penyakit hawar daun bakteri (Xanthomonas oryzae pv. oryzae) dan peningkatan produksi pada beberapa varietas tanaman padi sawah (Oryza sativa). Botek (2015) melaporkan bahwa introduksi mikroba antagonis seperti mikoriza, trichoderma dan rhizobakteri dapat mereduksi penggunaan pupuk anorganik hingga $25 \%$ dan meningkatkan produksi padi gogo kultivar Bakala. Taufik et al. (2019) melaporkan bahwa pemanfaatan cendawan endofit dapat menurunkan kejadian penyakit Vascular Streak Dieback (VSD) pada kakao

Upaya lain yang dapat dilakukan dalam rangka peningkatan produksi dan pengendalian penyakit tanaman dapat dilakukan pada aspek tanaman. Dari aspek tanaman, pemilihan varietas/kultivar dapat menentukan produksi dan ketahanan tanaman. Beberapa kultivar padi gogo lokal seperti Endokadia, Bakala, Nggalaru memiliki respon agak tahan terhadap penyakit blas $(P$. oryzae) dengan tingkat keparahan penyakit 5 sampai $10 \%$ dibandingkan dengan varietas nasional (Situ patenggang) dengan keparahan penyakit lebih dari $50 \%$ dan pada beberapa kondisi mengalami puso (Taufik $d k k ., 2009$ ).

\section{METODE PENELITIAN}

\section{Tempat dan Waktu}

Penelitian dilaksanakan di Desa Lamomea, Konda, Konawe Selatan,Sulawesi Tenggara, Laboratorium Proteksi Tanaman, dan Laboratorium Ilmu Tanah Fakultas Pertanian Universitas Halu Oleo Kendari, berlangsung pada bulan Mei sampai Oktober 2018.

\section{Alat dan Bahan}

Alat yang digunakan adalah hand traktor, cangkul, Kayu runcing, meteran, tali rafia, ring sampel, kertas label, timbangan, dan alat tulis menulis.

Bahan yang digunakan adalah benih padi gogo kultivar Ungoruno, pupuk organik (kotoran sapi), pupuk tunggal, dolomit, Trichoderma asperellium (Koleksi Gusnawaty H.S.), dan Paecilomyces sp. (Koleksi Muhammad Taufik).

\section{Rancangan Penelitian}

Penelitian menggunakan Rancangan Acak Kelompok (RAK) dalam pola faktorial dengan 2 faktor. Faktor pertama adalah pemupukan, yaitu:Tanpa pupuk anorganik (P0), pemupukan dengan pupuk anorganik $25 \%$ dari rekomendasi (P1), pemupukan dengan pupuk anorganik $50 \%$ dari rekomendasi (P2), pemupukan dengan pupuk anorganik $75 \%$ dari rekomendasi (P3) dan pemupukan dengan pupuk anorganik 100\% sesuai rekomendasi (P4). Faktor kedua adalah penggunaan cendawan endofit, yaitu:tanpa aplikasi cendawan endofit (C0), aplikasi Trichoderma asperellium (C1) dan aplikasi Paecilomyces sp. (C2).

\section{Penyiapan dan Aplikasi Cendawan Endofit}

Cendawan endofit yang digunakan adalah $T$. asperellium yang telah diperbanyak pada media beras ketan. Aplikasi T. asperellium dilakukan bersamaan dengan penanaman benih padi gogo dengan takaran 10 gram perlubang tanam. Aplikasi Paecilomyces sp dilakukan pada saat perendaman benih yaitu koloni yang tumbuh pada media PDA (Potato Dekstrose Agar) disuspensikan dalam aquades steril dengan kerapatan spora $1 \times 10^{8} \mathrm{CFU}$, kemudian dimasukkan kedalam wadah yang berisikan benih yang telah dicuci dengan air steril sebanyak 3 kali, selanjutnya benih diinkubasi selama 24 jam.

\section{Pengapuran dan Penambahan Bahan Organik (Kotoran Sapi )}

Pengapuran dan pemberian bahan organik dilakukan untuk memperbaiki sifak fisik tanah, kimia dan biologi tanah. Pengapuran dan pemberian bahan organik mengacu pada hasil analisis tanah dan dilakukan satu minggu sebelum tanam dengan dosis $1,08 \mathrm{~kg}_{\text {petak }}{ }^{-1}$ atau 2,40 ton ha ${ }^{-1}$ untuk kapur dan 5,57 $\mathrm{kg}$ petak $^{-1}$ atau 12,38 ton ha $^{-1}$ untuk bahan organik.

\section{Pemupukan dan Penanaman}

Dosis pupuk anorganik sesuai rekomendasi adalah $101,25 \mathrm{~g}$ petak $^{-1}$ atau $225 \mathrm{~kg} \mathrm{ha}^{-1}$ Urea, 56,25 $\mathrm{g}$ petak $^{-1}$ atau 
$125 \mathrm{~kg} \mathrm{ha}^{-1} \mathrm{SP} 36,45 \mathrm{~g} \mathrm{petak}^{-1}$ atau $100 \mathrm{~kg} \mathrm{ha}^{-1} \mathrm{KCl}$ (BPPP, 2009). Pupuk urea diberikan pada umur 14 hari setelah tanam, 42 hari setelah tanam, dan umur 55 hari setelah tanam. SP36 dan KCL diberikan pada saat tanam dengan cara disebar.

Penanaman dilakukan secara tugal dengan jarak tanam $30 \times 25 \mathrm{~cm}$, pada setiap lubang diisi 5 butir benih padi gogo.

\section{Variabel Pengamatan Fase Generatif Tanaman}

Pengamatan variabel produksi tanaman dilakukan pada tanaman sampel sebanyak 7 rumpun untuk tiap perlakuan dan kelompok. Pengamatan meliputi:

1. Waktu munculnya malai, dihitung dari saat tanam sampai tanaman yang bermalai mencapai lebih dari $50 \%$ dari populasi tanaman per petak.

2. Bobot 1000 bulir, dilakukan dengan menimbang berat 1000 bulir gabah isi pada kadar air 14\% (diperoleh dengan cara tradisisonal yaitu penjemuran selama 3 hari).

3. Hasil gabah kering, dihitung dengan menggunakan metode ubinan yang dikonversi dalam satuan hektar yang dapat dilakukan dengan menggunakan rumus :

Hasil gabah kering $=\frac{\text { Luas lahan } 1 \text { ha }}{\text { Luas Ubinan }} \times$ Bobot hasil ubinan

\section{Keparahan Penyakit}

Tingkat keparahan penyakit diamati pada akhir pengamatan dengan rumus :

Keterangan :

$$
\mathrm{KP}=\frac{\sum_{\mathrm{i}=1}^{\mathrm{n}}\left(\mathrm{n}_{\mathrm{i}} \times \mathrm{v}_{\mathrm{i}}\right)}{(\mathrm{N} \times \mathrm{Z})} \times 100
$$

$\mathrm{KP}=$ Keparahan Penyakit (disease severity) $\%$

\section{HASIL DAN PEMBAHASAN}

\section{Waktu Munculnya Malai}

Kombinasi pemupukan dengan $100 \%$ dari rekomendasi dan aplikasi Trichoderma sp. (P4C1) memberikan respon waktu munculnya malai tercepat $\mathrm{n}_{\mathrm{i}} \quad=$ jumlah daun dalam setiap kategori serangan

$\mathrm{v}_{\mathrm{i}} \quad=$ nilai numerik masing-masing kategori serangan

$\mathrm{Z} \quad$ =nilai numerik kategori serangan tertinggi

$\mathrm{N}=$ jumlah daun yang diamati

Nilai numerik kategori serangan diukur dengan melihat perbedaan tingkat keparahan serangan patogen pada daun tanaman yaitu: 0 = tidak ada serangan, $1=$ luas daun terserang kurang dari $1 \%, 3=$ luas daun terserang $1-5 \%, 5=$ luas daun terserang $6-25 \%, 7=$ luas daun terserang $26-50 \%$, dan $9=$ luas daun terserang 51 $100 \%$ (Silitongaet al., 2003).

Analisis perkembangan penyakit dari waktu ke waktu dilakukan dengan menggunakan total Area Under the Disease Progres Curva (AUDPC) menggunkan

$\boldsymbol{A U D P C}=\sum_{i=1}^{n}\left[\frac{Y_{i}+\boldsymbol{Y}_{i+1}}{2}\right]\left(\boldsymbol{t}_{i}-\boldsymbol{t}_{i+1}\right)$

Keterangan:

$\mathrm{Y}_{\mathrm{i}} \quad$ = Data keparahan penyakit pada waktu ke-i

$\mathrm{Y}_{\mathrm{i}+1}=$ Data keparahan penyakit pada waktu ke-i + 1

$\mathrm{t}_{\mathrm{i}} \quad=$ Waktu pengamatan ke-i

$\mathrm{t}_{\mathrm{i}+1}=$ Waktu pengamatan ke- $\mathrm{i}+1$

\section{Analisis Data}

Data hasil pengamatan dari fase vegetatif, fase generatif dan evaluasi ketahanan penyakit padi gogo dianalisis dengan menggunakan sidik ragam dan metode Uji Jarak Berganda Duncan (UJBD) untuk perlakuan yang berpengaruh nyata pada taraf kepercayaan $95 \%$.

dengan rata-rata 93,00 hari. Tanpa pupuk anorganik dan tanpa cendawan endofit (P0C0) memberikan respon munculnya malai terlambat dengan rata-rata 103 hari

Tabel 1. Pengaruh interaksi penggunaan pupuk anorganik dan cendawan endofit terhadap waktu munculnya malai pada padi gogo

\begin{tabular}{|c|c|c|c|c|c|c|c|}
\hline \multirow{2}{*}{ Pemupukan } & \multicolumn{5}{|c|}{ Mikroba } & & \multirow{2}{*}{ UJBD 0,05} \\
\hline & $\mathrm{CO}$ & & $\mathrm{C1}$ & & $\mathrm{C2}$ & & \\
\hline \multirow[t]{2}{*}{ P0 } & 103,00 & $\mathrm{~b}$ & 102,00 & $\mathrm{a}$ & 102,00 & $\mathrm{a}$ & $2=0,72$ \\
\hline & $\mathrm{t}$ & & $\mathrm{t}$ & & $\mathrm{t}$ & & \\
\hline \multirow[t]{2}{*}{ P1 } & 100,33 & $\mathrm{a}$ & 100,00 & $\mathrm{a}$ & 100,00 & $\mathrm{a}$ & $3=0,76$ \\
\hline & $\mathrm{s}$ & & $\mathrm{s}$ & & s & & \\
\hline \multirow[t]{2}{*}{$\mathbf{P 2}$} & 99,00 & $\mathrm{~b}$ & 98,33 & $\mathrm{a}$ & 98,67 & $\mathrm{a}$ & $4=0,78$ \\
\hline & $\mathrm{r}$ & & $\mathrm{r}$ & & $\mathrm{r}$ & & \\
\hline P3 & 97,00 & $\mathrm{~b}$ & 95,33 & $\mathrm{a}$ & 96,00 & $\mathrm{a}$ & $5=0,80$ \\
\hline P4 & $\begin{array}{c}\mathrm{q} \\
95,00\end{array}$ & $\mathrm{c}$ & $\begin{array}{c}q \\
93,00\end{array}$ & $\mathrm{a}$ & $\begin{array}{c}\mathrm{q} \\
94,00\end{array}$ & $\mathrm{~b}$ & \\
\hline
\end{tabular}

Keterangan: (a dan b menyatakan perbedaan antara perlakuan cendawan endofit, $\mathrm{p}$ dan $\mathrm{q}$ menyatakan perbedaan antara perlakuan pemupukan), $\mathrm{P} 0=$ tanpa pupuk anorganik, $\mathrm{P} 1=$ pemupukan anorganik $25 \%$ dari rekomendasi, $\mathrm{P} 2=$ pemupukan anorganik 50\% dari rekomendasi), P3 = pemupukan anorganik $75 \%$ dari rekomendasi, $\mathrm{P} 4=$ pemupukan 


\section{J. Berkala Penelitian Agronomi 7 (1) : 16 - 22 (2019)}

anorganik $100 \%$ dari rekomendasi, $\mathrm{C} 0=$ tanpa cendawan endofit, $\mathrm{C} 1=$ aplikasi $T$. asperellium,

Paecilomyces sp.

Bobot 1000 bulir

Respon bobot 1000 bulir padi gogo dari perlakuan pemupukan anorganik pada taraf cendawan endofit $(\mathrm{C} 1 \mathrm{dan}$

anorganik $100 \%$ dari rekomendasi (P4) memberikan respon C2) menunjukkan bahwa pemupukan dengan pupuk

hasil bobot 1000 bulir tertinggi yaitu 31,27 gram.

Tabel 2. Pengaruh interaksi penggunaan pupuk anorganik dan cendawan endofit terhadap bobot 1000 bulir padi gogo

\begin{tabular}{|c|c|c|c|c|c|c|c|}
\hline \multirow{2}{*}{ Pemupukan } & \multicolumn{6}{|c|}{ Cendawan Endofit } & \multirow{2}{*}{ UJBD 0,05} \\
\hline & $\mathrm{CO}$ & & $\mathrm{C1}$ & & $\mathrm{C2}$ & & \\
\hline \multirow[t]{2}{*}{ P0 } & 23,77 & $\mathrm{~b}$ & 25,23 & A & 25,20 & $\mathrm{a}$ & $2=2,01$ \\
\hline & q & & $\mathrm{r}$ & & $\mathrm{r}$ & & \\
\hline \multirow[t]{2}{*}{ P1 } & 25,10 & $\mathrm{a}$ & 26,87 & $\mathrm{a}$ & 26,43 & $\mathrm{a}$ & $3=2,11$ \\
\hline & $q$ & & $\mathrm{qr}$ & & $\mathrm{r}$ & & \\
\hline \multirow[t]{2}{*}{$\mathbf{P 2}$} & 28,13 & $\mathrm{a}$ & 28,27 & $\mathrm{a}$ & 27,67 & $\mathrm{a}$ & $4=2,17$ \\
\hline & $\mathrm{p}$ & & $q$ & & $q$ & & \\
\hline P3 & 28,33 & $\mathrm{a}$ & 29,37 & $\mathrm{a}$ & 29,37 & $\mathrm{a}$ & $5=2,22$ \\
\hline \multirow[t]{2}{*}{ P4 } & $\begin{array}{c}\mathrm{p} \\
27,80\end{array}$ & $\mathrm{~b}$ & $\begin{array}{c}\mathrm{p} \\
31,27\end{array}$ & $\mathrm{a}$ & $\begin{array}{c}\mathrm{pq} \\
31,27\end{array}$ & $\mathrm{a}$ & \\
\hline & $\mathrm{p}$ & & $\mathrm{p}$ & & $\mathrm{p}$ & & \\
\hline
\end{tabular}

Keterangan: (a dan $\mathrm{b}$ menyatakan perbedaan antara perlakuan cendawan endofit, $\mathrm{p}$ dan $\mathrm{q}$ menyatakan perbedaan antara perlakuan pemupukan), $\mathrm{P} 0=$ tanpa pupuk anorganik, $\mathrm{P} 1=$ pemupukan anorganik $25 \%$ dari rekomendasi, $\mathrm{P} 2=$ pemupukan anorganik 50\% dari rekomendasi), $\mathrm{P} 3=$ pemupukan anorganik $75 \%$ dari rekomendasi, $\mathrm{P} 4=$ pemupukan anorganik $100 \%$ dari rekomendasi, $\mathrm{C} 0=$ tanpa cendawan endofit, $\mathrm{C} 1=$ aplikasi $T$. asperellium, $\quad \mathrm{C} 2=$ aplikasi Paecilomyces sp.

\section{Hasil gabah kering}

Kombinasi pemupukan dengan $100 \%$ dari tertinggi yaitu 5,07 ton/ha. Tanpa pupuk anorganik dan rekomendasi dan aplikasi Trichoderma sp. (P4C1) tanpa cendawan endofit (P0C0) memberikan respon hasil memberikan respon hasil gabah kering per ha yang gabah kering terendah yaitu 2,98 ton/ha.

Tabel 3. Pengaruh interaksi penggunaan pupuk anorganik dan cendawan endofit terhadap hasil gabah kering padi gogo per ha

\begin{tabular}{|c|c|c|c|c|c|c|c|}
\hline \multirow{2}{*}{ Pemupukan } & \multicolumn{6}{|c|}{ Cendawan Endofit } & \multirow{2}{*}{ UJBD 0,05} \\
\hline & CO & & C1 & & $\mathrm{C} 2$ & & \\
\hline \multirow[t]{2}{*}{ P0 } & 2,98 & $\mathrm{~b}$ & 3,26 & a & 3,19 & $\mathrm{a}$ & $2=0,170$ \\
\hline & $\mathrm{t}$ & & s & & s & & \\
\hline \multirow[t]{2}{*}{$\mathbf{P 1}$} & 3,32 & $\mathrm{c}$ & 3,64 & $\mathrm{a}$ & 3,54 & $\mathrm{~b}$ & $3=0,178$ \\
\hline & s & & $\mathrm{r}$ & & $\mathrm{r}$ & & \\
\hline \multirow[t]{2}{*}{$\mathbf{P 2}$} & 3,76 & $\mathrm{c}$ & 4,19 & $\mathrm{a}$ & 4,02 & $\mathrm{~b}$ & $4=0,183$ \\
\hline & $\mathrm{r}$ & & $q$ & & $q$ & & \\
\hline P3 & 4,26 & $\mathrm{c}$ & 4,92 & $\mathrm{a}$ & 4,77 & $\mathrm{~b}$ & $5=0,187$ \\
\hline \multirow[t]{2}{*}{ P4 } & $\begin{array}{c}\mathrm{q} \\
4,66\end{array}$ & $\mathrm{c}$ & $\underset{5,07}{\mathrm{p}}$ & $\mathrm{a}$ & $\begin{array}{c}\mathrm{p} \\
4,92\end{array}$ & $\mathrm{~b}$ & \\
\hline & $\mathrm{p}$ & & $\mathrm{p}$ & & $\mathrm{p}$ & & \\
\hline
\end{tabular}

Keterangan: (a dan b menyatakan perbedaan antara perlakuan cendawan endofit, $\mathrm{p}$ dan $\mathrm{q}$ menyatakan perbedaan antara perlakuan pemupukan), $\mathrm{P} 0=$ tanpa pupuk anorganik, $\mathrm{P} 1=$ pemupukan anorganik $25 \%$ dari rekomendasi, $\mathrm{P} 2=$ pemupukan anorganik 50\% dari rekomendasi), P3 = pemupukan anorganik $75 \%$ dari rekomendasi, P4 = pemupukan anorganik $100 \%$ dari rekomendasi, $\mathrm{C} 0=$ tanpa cendawan endofit, $\mathrm{C} 1=$ aplikasi $T$. asperellium, $\mathrm{C} 2=$ aplikasi Paecilomyces sp. 


\section{J. Berkala Penelitian Agronomi 7 (1) : 16 - 22 (2019)}

\section{Keparahan Penyakit Blas}

Pada taraf cendawan Trichoderma sp. (C1), pemupukan anorganik $100 \%$ sesuai rekomendasi (P4) memberikan respon perkembangan penyakit blas terendah

yaitu $60,31 \%$ bulan. Tanpa pupuk anorganik dal 19 cendawan endofit (P0C0) memberikan perkemuanzan penyakit blas tertinggi $189,73 \%$ bulan.

Tabel 4. Pengaruh interaksi antara penggunaan pupuk anorganik dan aplikasi cendawan endofit terhadap perkembangan penyakit blas (Pyricularia oryzae) pada padi gogo

\begin{tabular}{|c|c|c|c|c|c|c|c|}
\hline \multirow{2}{*}{ Pemupukan } & \multicolumn{6}{|c|}{ Cendawan Endofit } & \multirow{2}{*}{ UJBD 0,05} \\
\hline & $\mathrm{CO}$ & & C1 & & $\mathrm{C2}$ & & \\
\hline \multirow[t]{2}{*}{ P0 } & 189,73 & $\mathrm{~b}$ & 153,41 & $\mathrm{a}$ & 156,94 & $\mathrm{a}$ & $2=20,60$ \\
\hline & $\mathrm{s}$ & & $\mathrm{r}$ & & $\mathrm{r}$ & & \\
\hline \multirow[t]{2}{*}{ P1 } & 156,36 & $\mathrm{a}$ & 141,37 & $\mathrm{a}$ & 143,43 & $\mathrm{a}$ & $3=21,59$ \\
\hline & $\mathrm{r}$ & & $\mathrm{r}$ & & $\mathrm{r}$ & & \\
\hline \multirow[t]{2}{*}{$\mathbf{P 2}$} & 144,47 & $\mathrm{~b}$ & 113,72 & $\mathrm{a}$ & 121,89 & $\mathrm{a}$ & $4=22,23$ \\
\hline & $\mathrm{qr}$ & & q & & $q$ & & \\
\hline P3 & 127,67 & $\mathrm{~b}$ & 74,14 & $\mathrm{a}$ & 82,97 & a & $5=22,73$ \\
\hline \multirow[t]{2}{*}{ P4 } & $\begin{array}{c}\mathrm{pq} \\
98,43\end{array}$ & $\mathrm{~b}$ & $\begin{array}{c}p \\
60,31\end{array}$ & $\mathrm{a}$ & $\begin{array}{c}p \\
62,61\end{array}$ & a & \\
\hline & $\mathrm{p}$ & & $\mathrm{p}$ & & $\mathrm{p}$ & & \\
\hline
\end{tabular}

Keterangan: (a dan b menyatakan perbedaan antara perlakuan cendawan endofit, $\mathrm{p}$ dan $\mathrm{q}$ menyatakan perbedaan antara perlakuan pemupukan), $\mathrm{P} 0=$ tanpa pupuk anorganik, $\mathrm{P} 1=$ pemupukan anorganik $25 \%$ dari rekomendasi, $\mathrm{P} 2=$ pemupukan anorganik 50\% dari rekomendasi), P3 = pemupukan anorganik $75 \%$ dari rekomendasi, $\mathrm{P} 4=$ pemupukan anorganik $100 \%$ dari rekomendasi, $\mathrm{C} 0=$ tanpa cendawan endofit, $\mathrm{C} 1=$ aplikasi $T$. asperellium, $\quad \mathrm{C} 2=$ aplikasi Paecilomyces sp.

\section{PEMBAHASAN}

Proses pertumbuhan tanaman dipengaruhi oleh faktor genetik dan lingkungan. Pertumbuhan tanaman dari faktor genetik bertumpu pada kemampuan dan kapasitas tanaman tersebut. Sedangkan dari faktor lingkungan, ketersediaan unsur hara sebagai faktor abiotik dan cendawan endofit sebagai faktor biotik merupakan salah satu yang berperan dalam pertumbuhan tanaman. Interaksi dari faktor genetik tanaman dengan faktor lingkungan tersebut dapat diukur melalui penampilan tanaman di lapangan. Pada fase vegetatif aplikasi cendawan endofit dapat mengurangi penggunaan pupuk anorganik. Hal ini dapat terlihat pada varibel tinggi tanaman dan jumlah anakan. Hasil pengamatan pada variabel tersebut menunujukkan bahwa aplikasi cendawan endofit terutama Trichoderma sp. yang memberikan respon terbaik terhadap pertumbuhan padi gogo dan dapat mengurangi penggunaan pupuk anorganik 50\% sampai $75 \%$ dari rekomendasi. Hal yang sama dilaporkan taufik et. al. (2016) bahwa introduksi mikroba antagonis termasuk Trichoderma sp. dapat mereduksi penggunaan pupuk anorganik hingga 50\% terhadap pertumbuhan padi gogo kultivar bakala.

Interaksi antara tanaman dan cendawan endofit diinisiasi oleh tanaman dengan mensekresikan eksudat akar sehingga cendawan endofit dapat berkembang di daerah perakaran tanaman (rhizosfer). Cendawan termasuk Trichoderma sp. dan Paecilomyces sp. yang mengkoloni perakaaran tanaman mengakibatkan terjadinya modifikasi lingkungan fisik dan kimia tanah yang akan mempengaruhi tanaman padi gogo. Perubahan kimia dapat terjadi sebagai akibat dari adanya humifikasi bahan organik atau terjadi proses mineralisasi berbagai bahan organik menjadi bentuk yang siap diserap oleh tanaman. Selain itu keberadaan mikroba yang mengkoloni perakaran tanaman mampu melakukan fiksasi nitrogen bebas menjadi bentuk yang dapat dimanfaatkan oleh tanaman. Hal ini sejalan dengan pendapat Poulton et. al. (2011) bahwa Trichoderma sp. berperan dalam menguraikan bahan organik yang mengandung bahan organik tanah seperti $\mathrm{N}, \mathrm{P}, \mathrm{S}$ dan $\mathrm{Mg}$ dan membantu tanaman tanaman menyerap unsur hara tertentu terutama fosfat. Peranan cendawan endofit sebagai bioferlizer tersebut diduga menjadi faktor yang berperan dalam pertumbuhan vegetatif dan generatif tanaman padi gogo meskipun ada penurunan dosis pupuk anorganik.

Cendawan endofit baik Trichoderma sp. maupun Paecilomyces sp. memiliki potensi untuk memproduksi metabolit sekunder yang bersifat antibiotik yaitu viridin dan trikomidin. Viridin dan Trikomidin dapat menghambat pertumbuhan atau bahkan mematikan jamur yang lain. Metabolit sekunder cendawan endofit. sebagai salah satu sumber senyawa penting untuk pengembangan senyawa antimikrobia dalam melaksanakan pertanian berkelanjutan. Adriansyah et. al. (2015) mengemukakan bahwa metabolit sekunder Trichoderma sp. memiliki daya hambat terhadap Pseudomonas solanacearum sebesar $35,98 \%$. secara in vitro. Hal yang sama dilaporkan Harni et. al. (2017) bahwa metabolit sekunder Trichoderma sp. berpotensi menekan 
intensitas penyakit vascular streak dieback (VSD) pada bibit kakao hingga $81,8 \%$.

Metabolit sekunder dapat menghambat pertumbuhan $P$. oryzae dengan adanya senyawa antibiotik yang berupa viridin dan trikomidin, dimana kedua senyawa tersebut bersifat antibiosis. Viridin dan trikomidin dapat menghasilkan enzim $\beta-1,3$ glukanase dan kitinase. Trichoderma sp. mampu menghasilkan enzim hidrolitik $\beta$ 1,3 glukonase, kitinase dan selulase (Sukamto, et.al. 1999 dalam Adriansyah et. al. 2015). Enzim- enzim tersebut secara aktif mendegradasi sel-sel cendawan lain yang sebagian besar tersusun dari bahan $\beta-1,3$ glukon dan kitin, sehingga mampu melakukan penetrasi ke dalam hifa jamur lain. Enzim $\beta-1,3$ glukonase dan kitinase diduga terkandung dalam metabolit sekunder Trichoderma sp. menyebabkan rusaknya kitin pada dinding sel $P$. oryzae. Kerusakan dinding cendawan lain dan adanya enzim $\beta-1,3$ glukonase di dekat sel akan menyebabkan ketidak seimbangan konsentrasi ion-ion dalam cairan, sehingga menyebabkan terjadinya osmosis. Osmosis yang berlangsung terus-menerus dapat menyebabkan lisis dalam membran sel dan akhirnya sel menjadi mati.

\section{KESIMPULAN}

Berdasarkan hasil penelitian ini dapat disimpulkan bahwa kombinasi perlakuan pupuk anorganik $75 \%$ dari rekomendasi dengan cendawan endofit $T$. asperellium (P3C1) dan Perlakuan pupuk anorganik $75 \%$ dengan Paecilomyces sp. (P3C2) memberikan respon terbaik dalam meningkatkan produksi dan ketahanan padi gogo terhadap penyakit blas.

\section{DAFTAR PUSTAKA}

Agrios, G.N., 2005. Plant Pathology. $4^{\text {th }}$ ed. Academic Press. New York.

Alexopoulus, C.J., Mims, C.W., Blackweel, M., 1996. Introductory Mycology. John Wiley \& Sons INC. Singapore. 866p.

Amir, M., Kustianto, B., Lubis, E. 1993. Pewarisan Ketahanan Terhadap Blas Daun (Pyricularia oryzae) Isolat 26 pada Beberapa Kultivar Padi. Risalah Kongres Nasional XII dan Seminar Ilmiah PFI. Yogyakarta.

Astriani, F., Fibriarti, B.L., Zul, D. 2014. Seleksi Isolat Jamur dalam Menghasilkan Hormon IAA (Indole Acetic Acid) Asal Tanah Gambut Desa Rimbo Panjang Kabupaten Kampar. JOM FMIPA Volume 1 No. 2.

Badan Penelitian dan Pengembangan Pertanian, 2009. Petunjuk Pelaksanaan Percobaan Uji Kultilokasi Padi (UML) Padi Gogo. Dikti.

Couch, B.C., Kohn, L.M. 2002. A Multilocus Gene Genealogy Concordant With Host Preference Indicates Segregation of A New Species, Magnaporthe oryzae, From M. grisea. Mycologia (94 (4): 683-693.

Geraldine A.M., Lopes, F.A.C., Carvalho, D.D.C., Barbosa, E.T., Rodrigues, A.R., Brandao, R.S., Ulhoa C.J., Junior, M.L. 2013. Cell wall-degrading enzymes and parasitism of sclerotia are key factors on field biocontrol of white mold by Trichoderma spp. Biological Control. 67:308-316.

Harman, G.E., C.R. Howell, A. Viterbo, I. Chet, and M. Lorito. 2004. Trichoderma species opportunistic, avirulent plant symbionts. Nature ReviewsMicrobiology. 2: 43-56.

Harni, R., Amaria, W., Syafaruddin, Mahsunah, H., 2017. Potensi Metabolit Sekunder Trichoderma spp. Untuk Mengendalikan Penyakit Vascular Streak Dieback (VSD) pada bibit kakao. Journal of Industrial and Beverage Crops Vol. 4 Nomor 2.

Hasfiah, Taufik, M., Wijayanto, T., 2012. Uji Daya Hasil dan Ketahanan Padi Gogo Lokal Terhadap Penyakit Blas (Pyricularia oryzae) Pada Berbagai Dosis Pemupukan. Berkala Penelitian Agronomi 1: 26-36.

Naher,. L., Yusuf, U.K, Ismail, A., Hossain A.K. 2014. Trichoderma spp. : A Biological Agensiat for Sustainable Management of Plant Diseases. Pak. J. Bot. Volume 46. No. 4.

Rodriguez R.J., White J.F., Arnold A.E., Redman R.S. 2009. Fungal endophytes: diversity and functional roles. New Phytol 182(2):314-30.

Silitonga, T. S., Somantri I. H., Daradjat A., Kurniawan H., 2003. Panduan Sistem Karakterisasi dan Evaluasi Tanaman Padi. Badan Penelitian dan Pengembangan Pertanian Komisi Nasional Plasma Nutfah. Bogor.

Sitohang F.R.H.,Siregar L.A.M., Putri L.A.P.2014.Evaluasi Pertumbuhan Dan Produksi Beberapa Varietas Padi Gogo (Oryza sativa L.) pada Beberapa Jarak Tanam Yang Berbeda Evaluation Of The Growth And Production Of Some Upland Rice Varieties (Oryza Sativa L.) inSeveral Different Spacing. Jurnal Online Agroekoteknologi Vol. 2(2) : $661-679$.

Stone J.K., Polishook J.D., White J.F. 2004. Endophytic fungi. Di dalam: Mueller GM, Bills GF, Foster MS, editor. Biodiversity of Fungi: Inventory and Monitoring Methods. Elsevier Academic Press.

Suganda, T., Yulia, E., Widiantini, F., Hersanti. 2016. Intensitas Penyakit Blas (Pyricularia oryzae Cav.) pada Padi Varietas Ciherang di Lokasi Endemik dan Pengaruhnya terhadap Kehilangan Hasil. Jurnal Agrikultura 2016, 27 (3): 154-159.

Sucipto I., Munif A., Suryadi Y., Tondok E.T. 2015. Eksplorasi Cendawan Endofit Asal Padi Sawah sebagai Agens Pengendali Penyakit Blas pada Padi Sawah (Exploration of Endophytic Fungi from Lowland Rice as a Biocontrol Agent of Blast Disease in Lowland Rice). Jurnal Fitopatologi Indonesia 11(6): 211-218

Tandisau, T., 2004. Evaluasi Ketahanan Plasma Nutfah Padi Gogo (Oriza sativa L.) Lokal Asal Kabupaten Muna Terhadap Cekaman Aluminium. Skripsi Fakultas Pertanian Universitas Haluoleo. Kendari.

Taufik, M dan Syair. 2009. Analisis Sifat Ketahanan Terhadap Blast Dan Efektivitas Serapan Hara Dan Air Pada Padi Gogo Unggul Lokal Potensi Produksi Tinggi (> $5 \mathrm{~T} / \mathrm{Ha}$ ) Di Sulawesi Tenggara. Laporan Penelitian Hibah Kompetitif Penelitian Sesuai 
J. Berkala Penelitian Agronomi 7 (1) : 16 - 22 (2019)

Unggulan Nasional Batch III. Lembaga Penelitian Unhalu.

Taufik, M., Wijayanto, T., Gusnawaty HS, Nurmas, A., Alam, S., Santiaji, L. Sarawa. 2016. Improvement of local upland rice utilizing mixture of microbes: resistance, yield and reduction of chemical ${ }^{r} \cdot 21$
International Journal of Biosciences.Vol. 9, No. 5:97107.

Taufik, M., Boer, D., Syair, Yusuf, D.N., Putri, N.P. 2019. The Use of Local Endophyte Fungus to Control Vascular Streak Dieback (Ceratobasidium theobromae). International Journal of Biosciences.Vol. 16, No. 1:183-193. 